\title{
Mapping the Applicability of Counselling In Educational Settings
}

Ms. Sabiha Alam Choudhury ${ }^{\dagger}$

\begin{abstract}
Counselling is a purposeful understanding of a person so as to promote self-understanding in that person. There is an urgent need of introducing and strengthening the counselling service in the schools and colleges to meet the various needs of the students. Along with the intellectual development, proper motivation and clarification of goals and ideas to pupils in conformity with their basic potentialities and social tendencies are important for the total development of the student. Professional counsellors in educational settings ought to develop and deliver comprehensive counselling programme supporting and promoting student achievement, which should include a systematic and planned programme delivery involving all students and enhancing the learning process. This study is based on the review of secondary literature in an attempt to highlight the utmost relevance of counselling services in an educational setting.
\end{abstract}

Key words: counselling, educational settings, comprehensive perspective

\footnotetext{
${ }^{\dagger}$ Ph.D Research Scholar, Gauhati University, Email: sabihaalam23@gmail.com

C2015 Alam. This is an Open Access article distributed under the terms of the Creative Commons Attribution License (http://creativecommons.org/licenses/by/2.0), which permits unrestricted use, distribution, and reproduction in any medium, provided the original work is properly cited.
} 


\section{Introduction}

Counselling is defined as the application of mental health, psychological or human development principles through cognitive, affective, behavioural or systemic interventions, strategies that address wellness, personal growth, or career development, as well as pathology. The Governing Council of the American Counselling Association (ACA), the largest professional organization representing counsellors, accepted this definition of the practice of professional counselling in October 1997 (ACA, 1997).

Counselling, according to Brammer and Shostrom, is defined as a way of relating and responding to another person so that he/she is helped to explore his thoughts, feelings and behaviour to reach a clear self-understanding. In addition, the person is helped to find and use his/her strengths to be able to cope more effectively with making appropriate decisions, or taking appropriate action.

Counselling denotes a professional relationship between a trained counsellor and a client. This relationship is usually person-to-person, although it may sometimes involve more than two persons. It is designed to help clients to understand and to clarify their views of their life space, and to learn to reach their self-determined goals through meaningful, well-informed choices and through resolution of problems of an emotional or interpersonal nature (Burks and Stefflre, 1970, 14).

In keeping with the above understanding, Counselling is a branch, which encompasses a wide variety of issues in diverse settings. It is a profession, which is distinguished by having a specific body of knowledge, meets all the standards for a profession and is unique from, as well as connected with, other mental health disciplines by both its emphasis and its history. Counsellors work in areas that involve relationships. These areas include intra-and interpersonal concerns relating to finding meaning and adjustment in such settings as educational institutions, families and careers. It meets the needs of a wide spectrum of people. Clients seen by counsellors have developmental or situational concerns that require help concerning adjustment or remediation. Their problems often require short-term intervention, but treatment may be extended to encompass disorders included in the Diagnostic and Statistical Manual of Mental Disorders of the American Psychiatric Association. Counsellors also draw from a number of theoretical approaches, including those that are cognitive, affective, behavioural, and systemic. These theories may be applied to individuals, groups, and families. It is a process that may be developmental or intervening. In other words, counsellors focus on goals of their clients. It involves both choice and change. In some cases, "counselling is a rehearsal for action" (Casey, 1996, 176). Counselling has not always been an encompassing and comprehensive profession. It has evolved over the years from very diverse disciplines and practices.

\section{Methodology}

The study is based on the assumption that counselling is a very important programme in educational settings. It is the process by which students are given advice on how to deal with emotional conflicts and personal problems both in the educational setting and how to incorporate the same in their daily life. The study is qualitative in nature and reviews data and literature to understand the relevance and the utmost necessity of counselling as a dynamic comprehensive practice in educational settings.

\section{Understanding Educational Settings}

The IRB-SBS defines an educational setting as any setting where one would go in order to have an educational experience. It is a place where people of different ages gain education, including preschools, childcare, elementary schools, and universities.

Educational settings have the main social responsibility of completing the socialisation process of the child. The family gets the child, but the modern family tends to leave much 
undone in the socialisation process. The school and other educational institutions have come into being in place of family to complete the socialisation process.

In English the term "Education" has been derived from two Latin words educate (educere) and educatum. "Educare" means to train or mould. It again means to bring up, to lead out, or to draw out, propulsion from inward to outward. The term "educatum" denotes the act of teaching. It throws light on the principles and practice of teaching. The term "educare" or "educere" mainly indicates development of the latent faculties of the child. However, these possibilities are at times beyond the expertise and acquaintance of the pupil, which demands the necessity of a professional who can know these and take appropriate methods to develop those powers. "Education according to Indian tradition is not merely a means of earning a living; nor is it only a nursery of thought or a school for citizenship. It is initiation into the life of spirit and training of human souls in the pursuit of truth and the practice of virtue" (Radhakrishnan). "Education develops in the body and soul of the pupil all the beauty and all the perfection he is capable of" (Plato). "Education is the creation of sound mind in a sound body. It develops man's faculty specially his mind so that he may be able to enjoy the contemplation of supreme truth, goodness and beauty of which perfect happiness essentially consists" (Aristotle).

From the above discussion, it is now clear that since the times of Plato to the modern times, various educationists have defined education in various ways. Actually, education in an educational setting is a synthesis of a host of elements. It includes knowledge and sensitivity of individuals, the society, the environment, the social fabric and the prevailing traditions. Hence, the definition and the practice of education in an educational setting ought to be a comprehensive and all-inclusive one. Thus, education may be defined as a purposive, conscious or unconscious, psychological, sociological, scientific and philosophical process, which brings about the development of the individual to the fullest extent and also the maximum development of society in such a way that both enjoy maximum happiness and prosperity. In short, education is the development of individual according to his needs and demands of society, of which he is an integral part.

Education, in its general sense, is a form of learning in which the knowledge, skills, and habits of a group of people are transferred from one generation to the next through teaching, training or research. Education frequently takes place under the guidance of others, but may also be autodidactic. Any experience that has a formative effect on the way one thinks, feels, or acts may be considered educational. Education is commonly divided into stages such as preschool, primary school, secondary school and then college, university or apprenticeship.

Counsellors are employed in a variety of work settings. In some, they function as generalists; in others, they may provide specialised services to specific populations. Both the settings and the number of emerging counselling specialities have increased in the recent years. All counsellors irrespective of their work settings identify themselves as part of a shared profession that is distinguished from other helping disciplines. As Charles Darwin discovered in his travels, a staggering variety of species have successfully adapted to their environments - 20,000 different butterflies, 40 kinds of parrots, and 300 species of hummingbirds. There is also potentially an endless variety of counsellors, each .species having successfully adapted to the demands of the work environment. Every client population, geographical area, cultural heritage, institutional policy, physical facility, and psychological climate subtly shapes a new species of counsellor. There are probably more similarities than differences among counsellors in various settings.

\section{Educational Counselling}

The field of educational counselling encompasses a wide range of ages, developmental stages, and types of problems. 
Counselling is a collaborative process in which the counsellor or psychologist facilitates the expansion of the pupil's view of life, enlarges his repertoire of coping resources and enables him to make choices for change in himself, the situation and the environment, without destructive consequences to self or others. The process is directed by the application of specialised skills and strategies in a therapeutic relationship with the pupil with problems. The goal of intervention is to help pupils manage these problems effectively so that their total development would not be impeded. Students of all ages face unique issues on a day-to-day basis that many adults either minimize or overlook altogether. In today's educational system, counsellors may have one of the most strenuous jobs of all. Not only must they make themselves available to every student within the educational setting, they must also serve a variety of functions that span a host of different categories and purposes.

Discipline in an educational setting has always been a top concern for teachers and educators. In recent years, there has also been an increasing emphasis on the role of counselling in the education process at all levels-primary, secondary and tertiary. In the context of education, discipline is especially concerned with promoting behaviours that conform to teacher expectations and/or change behaviours that do not (Hoover, 1997). On the other hand, counselling is a "short-term, interpersonal, theory-based, professional activity guided by ethical and legal standards that focuses on helping individuals to resolve developmental and situational problems" (Gladding, 1992). Discipline is often associated with punishment aimed at correcting behaviours whilst counselling denotes the presence of a helping relationship characterised by warmth and acceptance. The two processes are quite different, but their goals are similar-that is to bring about behavioural change in the pupils.

According to Wolfgang (1999), the Relationship-Listening Face of discipline is a therapeutic process that involves minimum use of power. The student is viewed as having the capability to change his own behaviour. If he misbehaves, it is because of inner emotional turmoil or a feeling of inadequacy. Allowing the student to 'talk it out' will help him develop insights and become more purposeful in his behaviour. This approach is akin to clientcentred therapy, an effective approach to counselling developed by Carl Rogers, the father of counselling psychology. Rogers believed that man has a natural capacity for growth and development, a strong desire to become mature, socially adjusted, independent and productive. The counsellor must rely on this inner force, not upon his own influence, for therapeutic changes in the counselee. To Rogers, the true benefit of counselling lies in the therapeutic nature of the counselling relationship. He postulated that if the counsellor can provide a non-threatening relationship characterised by non-judgemental acceptance, warmth and respect, the counselee will discover within himself the capacity to use that relationship for growth and change, and personal development will take place (Rogers, 1951). This indeed will facilitate the all-round development and growth of the pupil along with disciplining him without relying on the use of punishment or power, which would rather retard the healthy development of the mental and social aspects of the students.

Glasser (1972) formulated an eight-step procedure as a guide for the counselling process in educational set up:

- Be involved. Glasser emphasizes the need for the counsellor to communicate concern to the student, along with warmth and understanding.

- Focus on behaviour, not feelings. The emphasis here is on making the students aware of what they are doing that makes them feel the way they do.

- Focus on the present. The past is important only as it relates to present behaviours.

- Make value judgements. The clients are helped to self-evaluate their behaviour to determine whether it is responsible behaviour. 
- Make a plan. The counsellor works with the client to develop a specific course of action that will change irresponsible behaviour to responsible behaviour.

- Get a commitment. Glasser believes that a plan is worthwhile only if the client makes a specific commitment to carry it out.

- Accept no excuses. Since not all plans succeed, Glasser suggests that when a plan fails, one should focus on developing new, more realistic plans rather than investigating why the old plan failed.

- Eliminate punishment, but do not give up. Plan failures are not to be met with punishment, only with the natural consequences that the client has to live with. Glasser urges the counsellor not to give up when plans fail, but to repeat the whole counselling cycle all over again (Wubbolding, 1991).

Reality Therapy was introduced to Singapore in the early 1990s. In 1995, Dr William Glasser himself was invited to Singapore by the National Institute of Education to conduct training for hundreds of schoolteachers. Since then Reality Therapy as a counselling approach has been gaining popularity, especially among school counsellors, many of whom have reported success in using the model (Tan, 2002).

The Children Act 2004, the official stamp of the ECM agenda, places a duty on agencies working with children to co-operate in order to improve children's well-being. This agenda is nowhere more keenly reinforced than within a school community. The Office for Standards in Education (OFSTED) looks closely at a school's commitment to this framework and how closely students are supported. Long gone are the years of educational institutions as exclusively educational establishments.

The ECM agenda identifies five main outcomes for children, and the Children's Plan 2020 Goals, released in April 2008, align some ambitious objectives with the original five outcomes. These outcomes sit very comfortably within a counselling role. As a result, many schools and educational settings choose to develop their team to include such professionals as counsellors.

The five main outcomes are that students in an educational setting should:

- Be healthy - mentally, emotionally and sexually, and be able to choose not to use illegal drugs;

- Stay safe - from maltreatment, neglect, violence, sexual exploitation, bullying, crime and anti-social behaviour;

- Enjoy and achieve - to be ready for and attend school and college, to achieve personally, socially and academically;

- Make a positive contribution - play a part in decision making, developing positive relationships and selfconfidence, and learning to deal with changes;

- Achieve economic well-being - engage in further education or employment, live in decent homes with access to transport and material goods.

One of the main reasons for the UK Government initiating the ECM agenda in the first place was to move the focus from intervention to prevention because:

Too often children experience difficulties at home or at school, but receive too little help too late, once problems have reached crisis point.

(HM Government, 2003, 5)

Thus, decisions and choices drawn by personal conviction are more likely to be translated into action and this is where the role of the counsellor really comes into its own, enabling the educational community to fulfil these objectives.

Over the last few years, there has been a huge growth of interest in the fields of counselling and psychotherapy. This has manifested itself in a number of areas: in health care, in the family, in the workplace and of course, in educational settings. The development of a separate 
speciality of counselling in educational set-up has in part resulted from the decline of the traditional pastoral roles that teachers used to take on. They often find little time to undertake the extra-curricular activities, which in many countries were the normal expectations for teachers. Indeed, teachers have recently been constrained by the National Curriculum, Standard Assessment Tasks (SATs) and the general and very real pressures of work. Moreover, students have become more aware of their rights and are often the ones asking for counselling support to help them face the emotional hazards of growing up and development. Even the parents of young adults are keen to have a supportive adult in the educational place with whom their children can share problems. The requirements of the Children Act 1989 for pastoral provision in schools have encouraged some schools to set up a formalised counselling service. Principals and head teachers of schools and colleges also have recognised that the skills of psychotherapists and counsellors can be fruitfully employed in dealing with the tremendous range of problems that pupils present with.

Most students encounter challenges beyond the scope of teachers' awareness at some point during their educational careers. In experiencing such dilemmas, many students develop the adaptive coping skills that help them navigate life's difficult experiences. While some of these students may receive support from adults in their home and classroom environments, other students may not receive the quality or quantity of parental or classroom support they need. The lack of support prevents the achievement of academic and psychological stability (Fredericks, Blumenfeld, $\&$ Paris, 2004). These students may require additional support and intervention in order to support their optimal social, academic and career development. The perception of counsellors is now being studied and it is valuable to look at the ASCA National Model based on that real world insight (Dahir, Burnham \& Stone, 2009). It appears that many counsellors find one-on-one intervention directly correlating with their job satisfaction (Kolodinsky et. al., 2009).

The American School Counsellor Association (ASCA) has recognized the need for school counsellors to provide direct services (classroom lessons, individual planning sessions and responsive services) to every student by delivering a Comprehensive School Counselling Program (CSCP). A CSCP is a structured and results-based programme that consists of four components: guidance curriculum, responsive services, individual planning and system supports (Gysbers, 2010, 170). Following the launch of ASCA's National Model in 2003, state organizations began creating their own version of a comprehensive school-counselling programme. To date, "17 states have established models, 24 states are progressing in model implementation, and 10 states are at a beginning stage of model development" (Martin, Carey, \& DeCoster, 2009, para. 1). In states that have completed studies on the impact of CSCP (such as Missouri and Utah), Lapan, Gysbers and Kayson $(2007,4)$ found "that more fully implemented comprehensive guidance programs had a significant impact on student achievement". Similarly, Nelson, Fox, Haslam and Gardner (2007) found that in Utah, "students in high-implementing comprehensive counselling and guidance schools achieve higher levels of academic achievement and make better decisions about education and career planning than do students in matched lower-implementing schools".

Historically professional school counsellors have been asked to perform multiple duties as part of their daily work. "Some of these duties match the descriptions set forth by the national standards for school counselling programs, whereas others do not" (Wilkerson \& Bellini, 2006). In order to overcome this confusion and to focus in on what activities school counsellors should be engaged in, the American School Counsellor Association (ASCA) published a national model for school counselling (ASCA, 2002). It defines what a school counsellor is and clarifies the roles of school counsellors for the profession and for the public. Counselling at the 
college level involves understanding how college students of all ages learn, grow and develop. It is important that college counsellors in particular distinguish between problems students have tied to expected developmental struggles, such as autonomy, identity and intimacy, and more serious or chronic forms of psychological disturbance (Sharkin, 1997).

The variety of concerns that students deal with have increased in the second half of the twentieth century. The added importance placed on higher education has created a situation in which the ASCA National Model is more important than ever, but it also raises the standard that students are expected to reach. Educational administrators, teachers, parents and policy makers have begun to observe some of the more visible outcomes of these shifts in society. Adults who function in supervisory capacities also recognise that the pressures being borne by students at the elementary and secondary school level (particularly in the nation's public school system) are generating a wide range of academic, emotional, and social problems that would require more support for students. In the face of these societal changes within the average student's life, the school counselling movement was born (Dahir, 2004).

The current roles and functions of counsellors in educational settings are described and understood much better now than they were in the early part of the 20th century. Almost every year new data become available describing the typical practice of counsellors in educational settings. The earliest such study appears to have been a survey of the training and testing practices of practitioners conducted by Wallin (1914). Wallin found that most practitioners were not particularly well trained, nor were they providing services specific to their profession. The role of psychometrician was considered not only appropriate but also essential, and practice often was limited to the administration of the few techniques for measuring ability and achievement that were available at that time. In this role, the school psychologist facilitated the "sorting" of children into different educational programmes. The role soon expanded to include interventions, often-remedial instruction or counselling (Hildreth, 1930).

Roles and functions of educational counsellors have been shaped by many forces throughout the history of the profession, and these forces continue to shape new roles and functions while preserving traditional ones. In addition, just as students are influenced by many factors in their environments, the current roles and functions of individual educational counsellors are influenced by numerous personal, professional, and external variables, which indeed has a tremendous impact on the growth and development of the students as well as the educational setting.

The impetus for the development of educational counselling has a number of causes. Everyday life can be challenging and stressful for even the most resilient of students. Competitiveness, bullying, social exclusion, racism, family crisis, sibling rivalry, scholastic underachievement, abuse, peer pressure, etc. are few of the problems consistently faced by students which are brought up to the counsellor and demand their attention. Counselling as a profession is now better managed and regulated and there is an improved understanding of the benefits and limits of the practice of counselling. Some counsellors are more willing to work collaboratively with other colleagues in educational institutions as members of the staff team, thereby removing some of the mystique and scepticism previously associated with their practice.

A counsellor is in a position where he or she can support a student's long-term desire for higher education or vocation. Counsellors are able to do this in a way that teachers who are confined to a certain grade level or subject, for example, are unable to. According to Scarborough and Luke (2008), "comprehensive, developmental school counselling programming has been associated with numerous benefits for students and is considered current best practice" (Scarborough \& Luke, 2008 , 1) Student outcomes are highly 
mutable and are shaped by many aspects of students' lives that do not occur in the classroom. Trying to ascertain how to best deal with those out-of-school factors and how to best help a student who needs additional help is one of the most significant ways in which counselling can be most effective.

Counsellors in an educational setting help the students to get solutions on how to deal with psychological problems, which might affect their studies. Through this, the students are able to develop problem-solving skills, which to an extent help them deal with particular issues surrounding their lives. Students are advised on how to cope with different situations facing them in their academic and personal lives. They get to learn to live in harmony with others in the educational setting, and in doing so they learn to appreciate the people around them. It bridges the gap between the students and the educational administration. Counsellors aid them in getting comprehensive advice on career courses and jobs, which enable them to have an informed choice on the avenues available after their education. It allows students to talk about various things, which they feel uncomfortable talking about with their parents, which include things like drug abuse.

Patti Wallace, Lead Advisor, University and College Counseling conducted a year long, sector-wide piece of research into the impact of counselling on academic outcomes in educational institutions, with data contributed by 65 universities and FE colleges across the UK. All members of the Association for University and College Counselling (AUCC) were invited via the AUCC, Heads of University Counseling Services (HUCS) and FE Counsellors to contribute to this research by distributing questionnaires with four quantitative and two qualitative questions to all students who approached counselling in the academic year September 2011 to July 2012. Data from 5,537 students from 65 UK universities and FE colleges was submitted for quantitative analysis via SPSS. A smaller, but still significant subset of data from 1263 students from 53 universities and colleges was included in the qualitative analysis using Grounded Theory. The findings indicated that $54 \%$ of all student respondents indicated that counselling was either 'an important factor' or 'the most significant factor, and another $27 \%$ indicated that it was 'one of many factors' in helping them stay at university. Therefore, in total, $81 \%$ of students considered counselling to have helped them stay at university or college. Also $50.6 \%$ of all student respondents indicated that counselling was either 'an important factor' or 'the most significant factor', and another $28.4 \%$ that it was 'one of many factors' in helping them do better in their academic work. Therefore, in total, $79 \%$ of students considered counselling to have helped them do better in their academic work. In the dimension of employability $59.9 \%$ of all students indicated that counselling was either 'an important factor' or 'the most significant factor', and another $18.2 \%$ that it was 'one of many factors' in helping them develop skills useful for obtaining future employment. Therefore, in total, $78.1 \%$ of students considered that counselling helped them develop skills useful for obtaining employment.

Thus, it can be said that now more than ever, students must resist the urge to live only in the moment, but instead think ahead to their futures and make the right decisions. With the right counsellors on their side, students have a greater chance to succeed in their academic set up and beyond.

\section{A Comprehensive Discipline}

A major component of an educational counsellor's programme is consultation with parents, teachers, administrators, and outside referral sources. Children and adolescents are faced with a myriad of life stressors over which they have little or no control. Family transitions such as divorce and stepfamily living are such common occurrences that professionals often discount the emotional impact these changes have on children and youth. Academic difficulties related to learning disabilities, attention deficit disorder and other neurological difficulties make going to school a 
stressful experience for many children. These very serious issues affect children both emotionally and academically. Younger children have fewer resources developmentally and psychologically to improve their often dismal life situations. Teachers and other school personnel are often overwhelmed by the seriousness of children's reactions to these stressful issues, and they can clearly see how these stressors affect their students' abilities to learn and grow. It is evident to most educators that in order to help children and adolescents thrive in the educational environment; collaborative efforts must be made to improve the home and school environments. Significant adults in children's lives must initiate these efforts (White, Mullis, Earley, \& Brigman, 1995). Counsellors in educational settings work from a holistic, systemic approach in which they attempt to understand and assist the whole child in relationship to classroom, home, and other environments.

A comprehensive counselling programme is an integral component of the academic mission of the educational setting. Comprehensive educational counselling programmes, driven by student data and based on standards in academic, career and personal/social development, promote and enhance the learning process for all students.

A Comprehensive Guidance \& Counselling Program (CGCP) is a competency-based programmatic approach to school counselling and associated educational units (e.g., career, technical, nurses, school psychologists) which is designed to be:

- multi-systemic (school, home, and community)

- collaborative (educators, families, community members)

- developmental (aimed at helping students at their particular developmental level)

- proactive and prevention-minded (supports students before crisis)

- accountable to the stakeholders, and
- educationally focused (helps students to reach educational, career, and personalsocial goals)

The ASCA National Model graphic represents the operational structure and components of ASCA's National Model for school counselling programmes. It has four themes (school counsellor skills and attitudes) as Leadership, Advocacy, Collaboration and Systemic Change in the outer layer. In the central part, it shows the four elements of the ASCA National Model: Foundation, Management, Delivery and Accountability.

The ASCA National Model is a framework written to help provide guidance for school counselling programmes; this manuscript show school counsellors how to develop an inclusive counselling programme. The ASCA National Model has a concrete structure written to reflect a comprehensive approach to the programmes foundation, delivery management and accountability. It is designed to assure that every student receives the maximum benefit of the school counselling programme. This model delineates what all students from prekindergarten through 12th grade, should know, understand and be able to display in three domain areas which are academic, career, personal/social. It includes a holistic view of the student that will promote a positive self-image that allows them to grow and develop into productive citizens and contributing members of their society. The ASCA Model is preventive in design and developmental in nature. The elements and themes of the ASCA Model work in a collaborative way to assure that students are receiving the full benefit of the programme. The ASCA National Model is a data driven Model that is design for systemic change. The ASCA National Model is design to provide evidences of the importance of comprehensive school counselling programme.

Thus effective educational counselling programmes are a collaborative effort between the professional counsellor, families and other educators to create an environment promoting student achievement. Educational professional, including counsellors, value and respond to the 
diversity and individual differences in our societies and communities. Comprehensive counselling programmes in educational settings ensure equitable access to opportunities and rigorous curriculum for all students to participate fully in the educational process.

\section{Conclusion}

In the educational institutions, nowadays, there is a great importance and emphasis given on counselling. Counselling is a very important ingredient in shaping students' behaviour and performance especially in educational settings. Students with various problems in such settings need to be listened to. In an educational setting nowadays, there are many cases, which need to be handled by a trained counsellor. These include; psychological, family issues and above all indiscipline cases; which, if not handled professionally, can lead students to making wrong and uninformed decisions. The goal of intervention is to help pupils manage these problems effectively so that their total development would not be impeded. Thus, a comprehensive, developmental counselling programme in educational settings has been associated with numerous benefits for students and is considered current best practice.

\section{References}

Aggarwal, J. C. (2002). Theory \& Principles Of Education. New Delhi: Vikas Publishing House Pvt Ltd. p. 32.

American Counseling Association (1997). ACA Governing Council Meeting Minutes. October 17-19, 1997. p. 8. Retrieved from: http://www.counseling.org/docs/governingcouncil-minutes/1997-october-17-

19.pdf?sfvrsn=4

American Counseling Association (1999). U SStudent-Counsellor Ratio. Washington, DC: Author.

American School Counselor Association (ASCA). (2002). Ethical Standards for School Counselors. Retrieved from: https://www.schoolcounselor.org/asca/media/ asca/Resource\%20Center/Legal\%20and\%20Ethi
cal\%20Issues/Sample\%20Documents/EthicalSta ndards2010.pdf

Benshoff, J. M., \& Paisley, P. O. (1996). A Structured Model of Peer Consultation for School Counsellors. Journal of Counseling and Development, 74, 314-318.

Sahu, B. (2002). New Educational Philosophy. New Delhi: Sarup \& Sons. p. 14.

Brott, P. E., \& Myers, J. E. (1999). Development of Professional School Counselor Identity: A Grounded Theory. Professional School Counseling, 2, 339-348.

Burks, H. M., \& Stefflre, B. (1979) Theories of Counseling, 3rd ed. New York: McGraw-Hill.

Casey, J. (1996). Gail F. Farwell: A developmentalist who lives his ideas. The School Counselor, 43, 174-180.

Dahir, C. (2004). Supporting a nation of learners: The role of school counselling in education reform. Journal of Counselling and Developement, 82(3), 344-353.

Dahir, C., Burnham, J., Stone, C. (2009). Listen to the voices: School counselors and comprehensive school counseling programs. Professional School Counseling, 12, 182-192.

Denholm, C. J. (1989). Child and Youth Care in School Settings: Maximizing Support and Minimizing friction. The Journal of Child \& Youth Care Work, 5, 53-61.

DfES. (2003). Every Child Matters: Presented to Parliament by the Chief Secretary to the Treasury by Command of Her Majesty, September 2003. London: The Stationery Office, Cm5860/Department for Education. Retrieved from: http://webarchive.nationalarchives.gov.uk/201 30401151715/https://www.education.gov.uk/p ublications/eOrderingDownload/CM5860.pdf

Fredricks, J. A., Blumenfeld, P. C., \& Paris, A. H. (2004). School engagement: Potential of the concept, state of the evidence. Review of Educational Research, 74, 59-109.

George, R. L. \& Cristiani, T. S. (1995). Counseling: Theory and Practice. Allyn \& Bacon. 
Gibson, L., \& Mitchell, H. 2008. Introduction to Counseling and Guidance. New Jersey: Pearson Education, Inc.

Gladding, S. T. (1992). Counseling: A Comprehensive Profession. New York: Macmillan.

Glasser, W. (1972). Identity society. New York: Harper \& Row.

Gysbers, N. C., \& Henderson, P. (2001). Comprehensive Guidance and Counselling Programs: A Rich History and a Bright Future. Professional School Counseling, 4, 246-256.

Gysbers, N. C. (2010). School counseling principles. Remembering the past, shaping the future: $A$ history of school counseling. Alexandria, VA: American School Counselor Association.

Hoover, R. L., \& Kindsvatter, R. (1997). Democratic Discipline: Foundation and Practice. New Jersey: Prentice Hall.

Hayes, R. L., Paisley, IV. O., Phelps, R. E., Pearson, G., \& Salter, R. (1997). Integrating Theory and Practice: Counselor EducatorSchool Counselor Collaborative. Professional School Counseling, 1, 9-12.

Hildreth, G. H. (1930). Psychological service for school problems. Yonkers-on-Hudson, NY: World Book.

Kolodinsky, P., Draves, P., Schroder, V., Lindsey, C., Zlatev, M. (2009). Reported Levels of Satisfaction and Frustration by Arizona School Counselors: A Desire for Greater Connections with Students in a Data-Driven Era. Professional School Counseling, 12, 193-199.

Lapan, R.T, Gysbers, N.C., \& Kayson, M. A. (2007). Missouri school counselors benefit all students. Jefferson City, Mo: Missouri Department of Elementary and Secondary Education.

Martin, I., Carey, J. C., \& DeCoster, K. (2009). A national study of the current status of state school counseling models. Professional School Counseling, 12(5), 378-386.

Nelson, D. E., Fox, D. G., Haslam, M., \& Gardner, J. (2007). An evaluation of Utah's comprehensive guidance program: The fourth major study of Utah's thirteen-year program. Salt Lake City, UT: Institute for Behavioral Research in Creativity. Retrieved from : http://www.schools.utah.gov/cte/documents/g uidance/publications/Research_AnEvaluationUt ahsCCGP2007.pdf

Rogers, C. (1951). Client-centred Therapy, Boston: Houghton Mifflin.

Scarborough, J. L., \& Luke, M. (2008). School counselors walking the walk and talking the talk: A grounded theory of effective program implementation. Professional School Counseling, 11(6), 404-416.

Sharkin, B. S. (1997). Increasing Severity of Presenting Problems in College Counseling Centers: A Closer Look. Professional School Counseling, 75, 275-281.

Tan, E. (2002). Counselling Psychology in Singapore: Development, Issues and Challenges. In Tan, A.G. and Goh, M. (Ed). Psychology in Singapore: An Emerging Discipline. Singapore: McGraw Hill, 83-101.

Wallin, J. E. W. (1914). The mental health of the school child. New Haven, CT: Yale University Press.

Wilkerson, K., \& Bellini, J. (2006). Intrapersonal and organizational factors associated with burnout among school counselors. Journal of Counseling and Development, 84, 440-450.

White, J., Mullis, F., Earley, B., \& Brigman, G. (1995). Consultation on schools: The counselor's role. Portland, ME: J. Weston Walch.

Wolfgang, C. H. (1999). Solving Discipline Problems: Methods and Models for Today's Teachers. Allyn and Bacon.

Wubbolding, R. (1991). Understanding Reality Therapy. New York: Harper Collins. 